\title{
Water Environment Early Warning in China Ningxia Section of the Yellow River Based on WASP Model
}

\author{
Feng Jing ${ }^{1}$, Sun Zhanchao ${ }^{1}$, He Chengmin ${ }^{2}$ \\ ${ }^{1}$ College of Environmental Science and Engineering, Chang' an University, Xi'an, Shannxi, China \\ ${ }^{2}$ Shaanxi Province Hydrology and Water Resources Survey Bureau, Xi'an, Shannxi, China \\ Email address: \\ 1277322080@qq.com (Feng Jing), 18537860075@163.com (Sun Zhanchao), 564863262@qq.com (He Chengmin)
}

\section{To cite this article:}

Feng Jing, Sun Zhanchao, He Chengmin. Water Environment Early Warning in China Ningxia Section of the Yellow River Based on WASP Model. International Journal of Environmental Monitoring and Analysis. Vol. 3, No. 5, 2015, pp. 334-340. doi: 10.11648/j.ijema.20150305.24

\begin{abstract}
Ningxia is the severe water shortage in one of the China's provinces, the Yellow River as the main surface water in Ningxia, since the 90s of last century, water flow in upstream of the Yellow River have been decreasing, and with the advance of "One Belt One Road" conception, the rapid economic and social development in Ningxia, and water environment issues have become increasingly prominent, which seriously restrict the sustainable development of this area. In this paper, WASP model was used to simulate the Ningxia section of the Yellow River water quality, mainly on the water quality monitoring data in 2011 as the current year for simulation of early warning, and considered under the condition of different inflow and water quality improvement the Yellow River water quality early warning. The analysis found that the water quality of the Yellow River is mainly affected by the concentration of the drain, actual the water flow in upstream of the Yellow River has little influence on the water quality.
\end{abstract}

Keywords: Water Environment Early Warning, WASP Model, Different Hydrological Years

\section{基于WASP模型的黄河宁夏段水环境预警}

\section{冯晶 ${ }^{1}$, 孙占超 ${ }^{1}$ 贺成民 ${ }^{2}$}

${ }^{1}$ 环境科学与工程学院, 长安大学, 西安, 陕西, 中国

${ }^{2}$ 陕西省水文水资源勘测局, 西安, 陕西, 中国

\section{邮箱}

1277322080@qq. com（冯晶），18537860075@163.com（孙占超），564863262@qq. com（贺成民）

摘要：宁夏是中国重度缺水省区之一, 黄河作为宁夏区内主要的地表水源, 自上世纪 90 年代起, 来水持续偏枯, 并且伴 随着 “一带一路” 构想的推进，宁夏经济社会快速发展，同时水环境问题也日益突出，严重制约了宁夏的可持续发展。 本文利用WASP模型对黄河宁夏段水质进行模拟，主要以2011年水质监测资料作为现状年进行模拟预警，并且考虑上游 不同来水水质改善条件下的黄河水质预警。分析发现黄河水质主要受到排水沟排放浓度的影响，上游来水对黄河水质 影响较小。

关键字：水环境预警, WASP模型, 不同水文年

\section{1. 引言}

黄河是宁夏境内主要的地表水源, 由中卫市南长滩入 境, 流经卫宁平原、银川平原, 至石嘴山市头道坎北麻黄
沟出境。宁夏引黄灌溉历史始于秦代, 至今已有两千多年, 沿黄两岸沟渠纵横、土地肥沃, 中国自古便有 “天下黄河 富宁夏” 的说法, 黄河水资源已成为宁夏区域经济社会发 展的重要战略资源。但是, 黄河水资源在支撑宁夏社会经 
济快速发展的同时, 也承纳了大量农田退水、工业和生活 污废水, 水污染日益加重, 使黄河干流宁夏段水环境安全 面临着严峻考验 $[1-4]$ 。

\section{2. 研究方法}

基于中国黄河干流宁夏段的地形特征、干流水环境特 征和水动力学条件分析可知, 黄河河道属于宽浅型, 水深 远小于河宽, 且干流流量与污水流量之比远大于 $10-20$, 认为污染物在河道中可在短时间内混合均匀, 其垂向和横 向的污染物浓度梯度变化可忽略不计, 污染物主要靠断面 纵向混合作用向前输移, 河流水力要素和水质状况均可采 用断面平均值 [5-7]。因此, 可建立一维数学模型来模拟 河道内水流运动规律及入河污染物的迁移扩散特征。本次 选取WASP模型中的EUTR0模块建立黄河干流水质预警模型, 根据2011年水量、水质监测数据, 对NH3-N、CODMn、T-P 浓度进行预警研究。根据中国黄河干流水环境的特点, 将 黄河水体分为下河沿至青铜峡段（卫宁段）、青铜峡至石 嘴山段（青石段）, 结合地形测绘资料, 将黄河干流卫宁 段概化为 27 段, 青石段概化为 44 段, 其中将卫宁段最后一 个断面的输出数据作为青石段的初始数据输入模型中 [8-14]。

\section{3. 预警分析}

\section{1. 黄河干流水环境预警警度分级}

黄河干流水环境预警以中国《地表水环境质量标准》 （GB3838-2002）为预警判据, 建立蓝色、绿色、黄色、 橙色和红色五个预警级别, 警情分别从无警、轻警、中警、 重警到巨警 (表1)。蓝色预警代表监测指标的浓度较小, 无警情; 绿色预警代表监测指标的浓度有所增加, 但不会 造成大的影响, 为轻警; 黄色预警代表监测指标的浓度有 明显的增加, 应该引起有关部门重视, 为中警; 橙色预警 代表污染物已经对黄河生态环境产生了威胁, 应立即调查 并进行相关处理, 为重警; 红色预警代表警情已相当严重, 已达到 $\mathrm{V}$ 类或劣 $\mathrm{V}$ 类水质标准, 为巨警 $[15]$ 。

表1 黄河干流水质预警指标警度分级表。

\begin{tabular}{llllll}
\hline $\begin{array}{l}\text { 监测指标 } \\
(\mathrm{mg} / \mathrm{L})\end{array}$ & I 类标准 & II 类标准 & III类标准 & IV类标准 & V类标准 \\
\hline $\mathrm{COD}_{\mathrm{ln}}$ & $\leqslant 2$ & $\leqslant 4$ & $\leqslant 6$ & $\leqslant 10$ & $>10$ \\
$\mathrm{NH}_{3}-\mathrm{N}$ & $\leqslant 0.15$ & $\leqslant 0.5$ & $\leqslant 1$ & $\leqslant 1.5$ & $>1.5$ \\
$\mathrm{TP}$ & $\leqslant 0.02$ & $\leqslant 0.1$ & $\leqslant 0.2$ & $\leqslant 0.3$ & $>0.3$ \\
预警等级 & 蓝色预警 & 绿色预警 & 黄色预警 & 橙色预警 红色预警 \\
\hline
\end{tabular}

\section{2. 黄河干流水环境预警}

\section{2. 1. 黄河干流水环境现状预警}

分别对黄河干流卫宁段和青石段国控、区控监测断面, 对预警指标警度的年内逐月动态变化进行了分析。其中卫 宁段选取下河沿和金沙湾断面, 青石段选取青铜峡断面、 叶盛公路桥断面、银古公路桥断面、平罗黄河大桥断面和 麻黄沟断面, 确定水质现状警度 $[16]$ 。
由图1、2、3可知，卫宁段下河沿断面和金沙湾断面 水体 $\mathrm{COD}_{\text {丩nn }}$ 、 $\mathrm{TP}$ 浓度基本相同; $\mathrm{NH}_{3}-\mathrm{N}$ 浓度变化趋势相同, 部分时段金沙湾断面 $\mathrm{NH}_{3}-\mathrm{N}$ 浓度大于下河沿断面浓度。现 状年的1、3、4、9月，下河沿、金沙湾断面水体COD浓度 达到 I类水质标准, 为蓝色预警状态, 无警情; 其它月份 为 II类水标准, 达到绿色预警状态, 为轻警; 下河沿、金 沙湾断面 $\mathrm{NH}_{3}-\mathrm{N}$ 浓度基本都达到 $\mathrm{II}$ 类水质标准, 为绿色预 警状态，仅在 3 月份和 10 月份部分时间 $\mathrm{NH}_{3}-\mathrm{N}$ 浓度达III类 水标准, 预警级别变为黄色预警, 为中警; 水体TP浓度从 1 月中旬到2月中旬、6月中旬到 10 月末均满足III类水质标 准, 预警级别为黄色预警, 警情为中警; 其他月份TP浓度 均为 II类水标准, 预警级别为绿色预警, 警情为轻警。对 比可知, $\mathrm{COD}_{\mathrm{vn}} 、 \mathrm{NH}_{3}-\mathrm{N}$ 和TP三个预警指标浓度在 4 月 -11 月 期间均有明显变化, 主要受排水沟入黄水体污染物浓度的 直接影响。

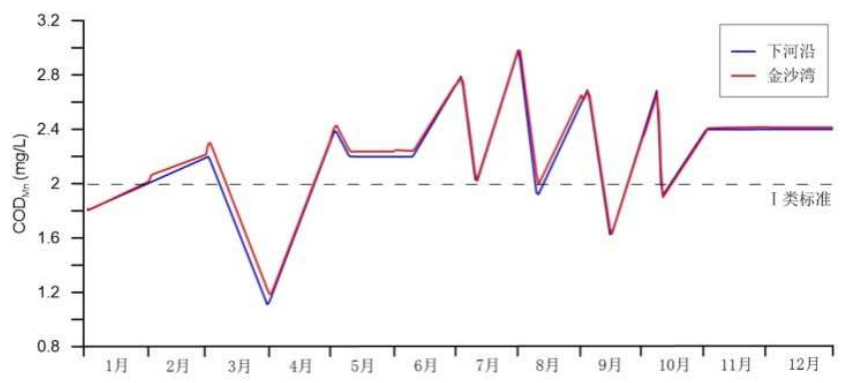

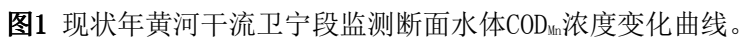

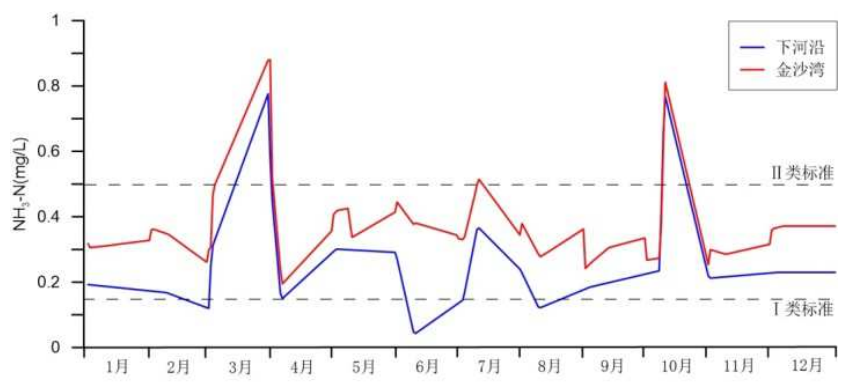

图2 现状年黄河干流卫宁段监测断面水体 $\mathrm{NH}_{3}-\mathrm{N}$ 浓度变化曲线。

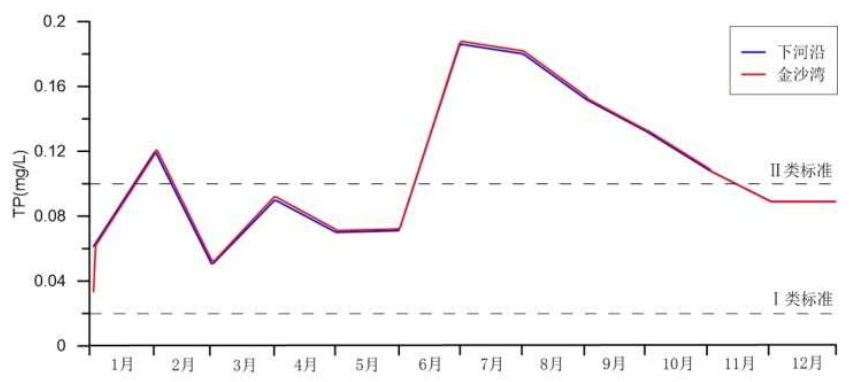

图3 现状年黄河干流卫宁段监测断面水体TP浓度变化曲线。

由图4可知, 黄河干流青石段中, 青铜峡断面水体 $\mathrm{COD}_{\mathrm{yn}}$ 浓度最小, 麻黄沟断面 $\mathrm{COD}_{\text {nn }}$ 浓度最大, 沿程水体 $\mathrm{COD}_{\text {nn }}$ 浓度 呈增加趋势。总体上, 各断面水体 $\mathrm{COD}_{\mathrm{yn}}$ 浓度达到 $\mathrm{II}$ 类水标 准, 为绿色预警状态, 警情为轻警。在 4 月和 8 月, 水体 $\mathrm{COD}_{\mathrm{Nn}}$ 浓度有一定幅度的升高, 其中8月份警情加重, 达到黄色 
预警状态; 由图5可知, 黄河水体 $\mathrm{NH}_{3}-\mathrm{N}$ 浓度沿程呈增加趋 势，受入黄污染物浓度影响，各段面 $\mathrm{NH}_{3}-\mathrm{N}$ 浓度随时间波 动较大。总体上, $\mathrm{NH}_{3}-\mathrm{N}$ 浓度基本满足 II、III类水质标准, 为绿色预警和黄色预警状态，警情为轻警和中警。其中， 3 月、7月和 8 月各断面水体 $\mathrm{NH}_{3}-\mathrm{N}$ 浓度均有所增大, 水质超 过IV类水标准，警情增加，变为橙色预警状态，应引起有 关部门重视，应适当控制入黄水体污染物浓度; 由图6可
知, 黄河水体TP浓度沿程呈增加趋势, 麻黄沟断面水体 TP 浓度最大。受入黄污染物浓度影响, 各段面TP浓度随时间 波动较大。总体上, TP浓度基本满足 II、III水质标准, 为绿色预警和黄色状态, 警情为轻警和中警。仅在 $7 、 8$ 月各断面水体TP浓度均有所增大, 水质超过III类水标准, 警情增加, 变为橙色预警状态。

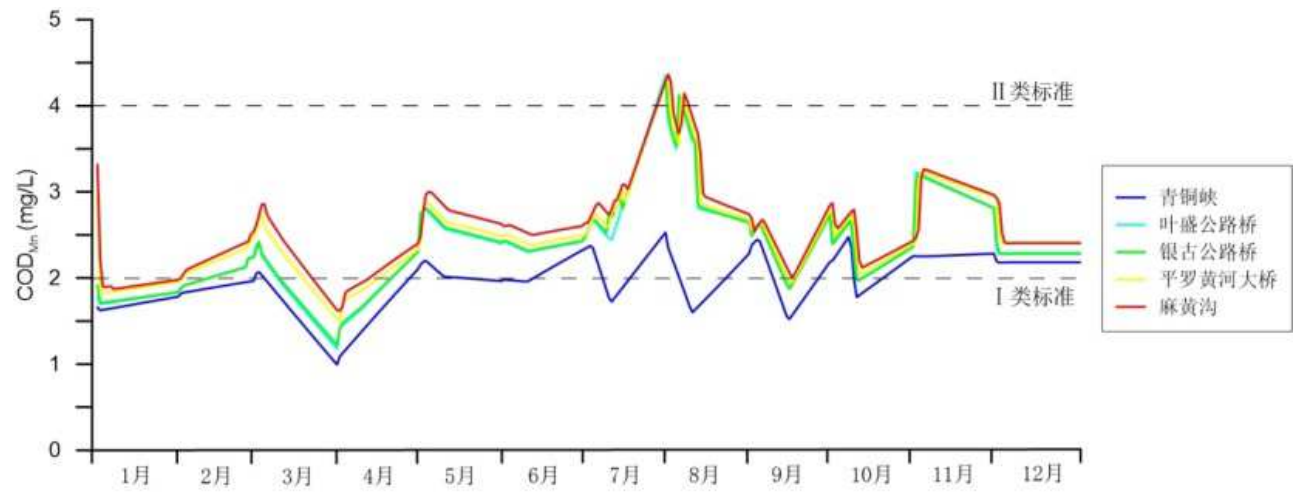

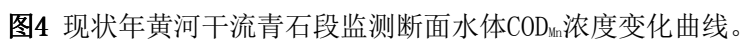

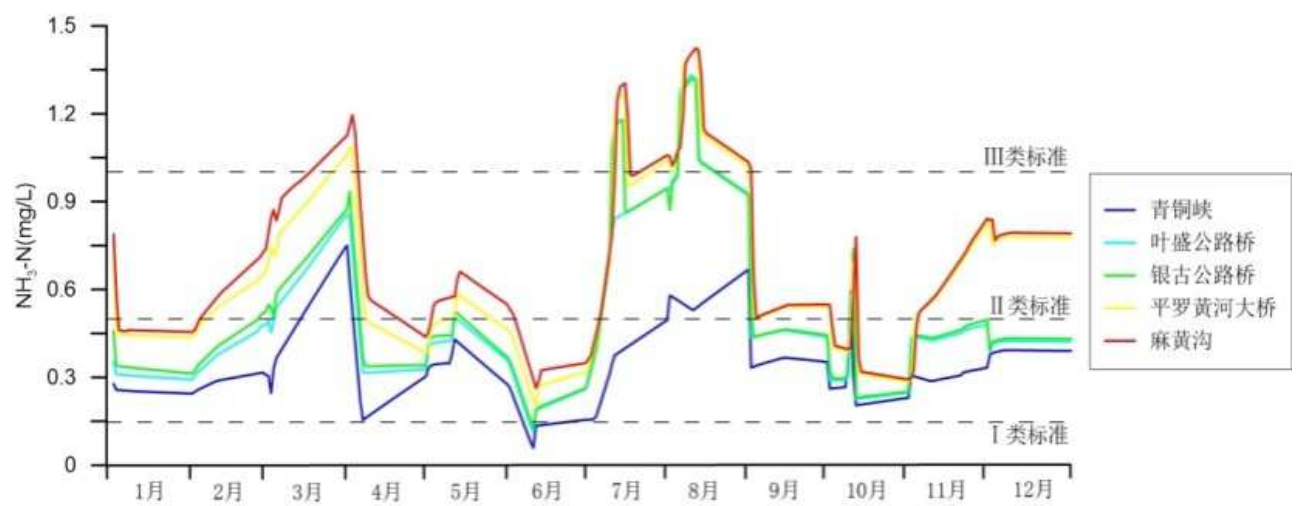

图5 现状年黄河干流青石段监测断面水体 $\mathrm{NH}_{3}-\mathrm{N}$ 浓度变化曲线。

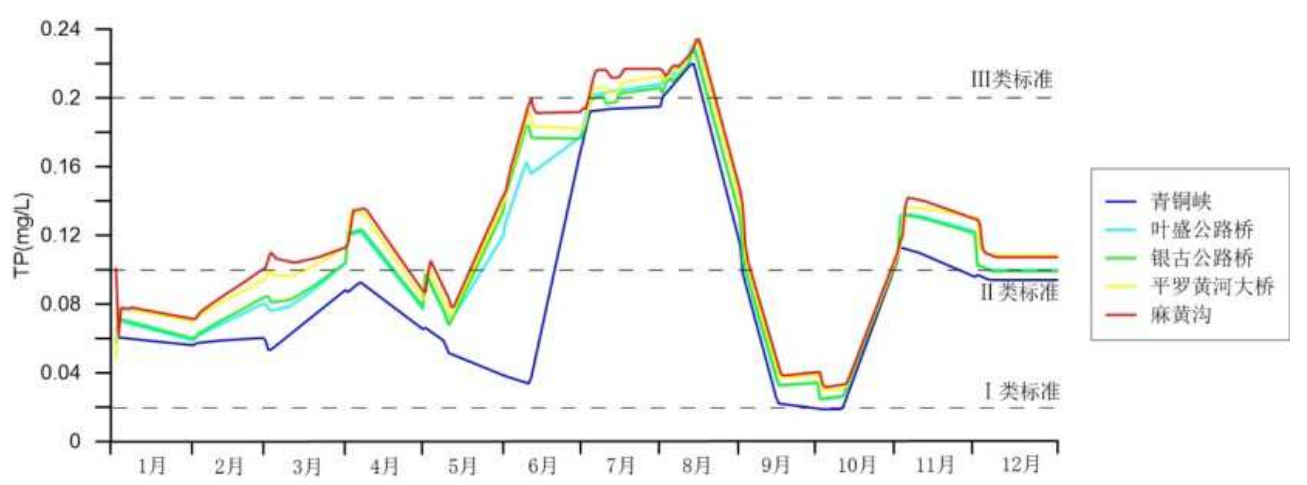

图6 现状年黄河干流青石段监测断面水体TP浓度变化曲线。

综上可得, 中国黄河干流 $\mathrm{COD}_{\mathrm{IIn}} 、 \mathrm{NH}_{3}-\mathrm{N}$ 和TP浓度变化 较大的断面为下河沿一金沙湾断面、青铜峡一叶盛公路桥 断面和银古公路桥一平罗黄河大桥断面, 其水体污染状况 和排水沟排污情况见表 2 。下河沿一金沙湾断面水体主要 污染因子为 $\mathrm{NH}_{3}-\mathrm{N}$, 主要受第四排水沟和红柳沟排污影响,
在排污量增大的 2 月、 6 月和 12 月黄河水体 $\mathrm{NH}_{3}-\mathrm{N}$ 浓度明显 升高; 青铜峡一叶盛公路桥断面主要受清水沟、南干沟和 中干沟排污影响，6-8月和11月排水沟排污浓度的增加使 黄河水体 $\mathrm{COD}_{\mathrm{In}} 、 \mathrm{NH}_{3}-\mathrm{N}$ 和TP均有明显升高; 银古公路桥一 
平罗黄河大桥断面主要受第二排水沟和永二干沟排污影 响, 中国黄河水体 $\mathrm{NH}_{3}-\mathrm{N}$ 浓度在 12 月明显升高。

表2 各断面水体污染状况统计。

\begin{tabular}{|c|c|c|c|c|c|}
\hline 断面 & 入黄排水沟 & $\begin{array}{l}\text { 主 要 污 } \\
\text { 染因子 }\end{array}$ & 浓度变化特征 & 原因 & $\begin{array}{l}\text { 影响水质主 } \\
\text { 要排水沟 } \\
\end{array}$ \\
\hline $\begin{array}{l}\text { 下河沿一金沙湾 } \\
\text { 断面 }\end{array}$ & $\begin{array}{l}\text { 第一排水沟 (中卫 } \\
\text { 市)、第四排水沟、 } \\
\text { 红柳沟 }\end{array}$ & $\mathrm{NH}_{3}-\mathrm{N}$ & $\begin{array}{l}2 \text { 月浓度升高 } 0.16 \mathrm{mg} / \mathrm{L} \\
6 \text { 月浓度升高 } 0.31 \mathrm{mg} / \mathrm{L} \\
12 \text { 月浓度升高. } 12 \mathrm{mg} / \mathrm{L}\end{array}$ & $\begin{array}{l}\text { 2月第四排水沟 } \mathrm{NH}_{3}-\mathrm{N} \text { 浓度 } 31.90 \mathrm{mg} / \mathrm{L} \text { (1月浓度 } 1.5 \text { 倍); } \\
6 \text { 月红柳沟 } \mathrm{NH}_{3}-\mathrm{N} \text { 浓度 } 2.80 \mathrm{mg} / \mathrm{L} \text { (1月浓度3.2倍); } \\
12 \text { 月第四排水沟 } \mathrm{NH}_{3}-\mathrm{N} \text { 农度 } 18.50 \mathrm{mg} / \mathrm{L}(11 \text { 月浓度 } 1.3 \text { 倍); } \\
12 \text { 月红柳沟 } \mathrm{NH}_{3}-\mathrm{N} \text { 浓度8. } 40 \mathrm{mg} / \mathrm{L}(11 \text { 月 } 3.5 \text { 倍） }\end{array}$ & $\begin{array}{l}\text { 第四排水沟 } \\
\text { 红柳沟 }\end{array}$ \\
\hline \multirow[t]{2}{*}{$\begin{array}{l}\text { 青铜峡一叶盛公 } \\
\text { 路桥断面 }\end{array}$} & \multirow[t]{2}{*}{$\begin{array}{l}\text { 中干沟、清水沟、 } \\
\text { 南干沟、罗家河 }\end{array}$} & $\mathrm{NH}_{3}-\mathrm{N}$ & $\begin{array}{l}\text { 8月浓度升高 } 1.7 \mathrm{mg} / \mathrm{L} \\
11 \text { 月浓度升高 } 1.1 \mathrm{mg} / \mathrm{L} \\
\text { 7月浓度升高 } 0.58 \mathrm{mg} / \mathrm{L} \\
8 \text { 月浓度升高 } 0.9 \mathrm{mg} / \mathrm{L}\end{array}$ & 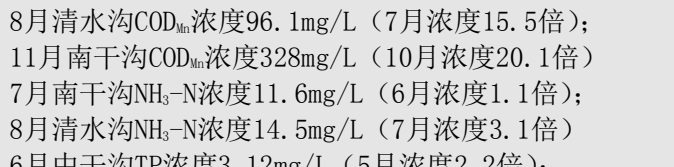 & \multirow{2}{*}{$\begin{array}{l}\text { 清水沟 } \\
\text { 南干沟 } \\
\text { 中干沟 }\end{array}$} \\
\hline & & $\mathrm{TP}$ & $\begin{array}{l}6 \text { 月浓度升高 } 0.13 \mathrm{mg} / \mathrm{L} \\
11 \text { 月浓度升高 } 0.02 \mathrm{mg} / \mathrm{L}\end{array}$ & 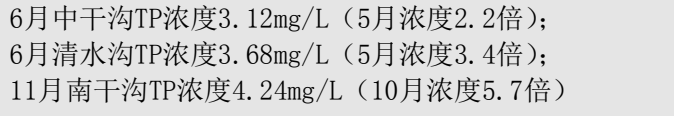 & \\
\hline $\begin{array}{l}\text { 银古公路桥一平 } \\
\text { 罗黄河大桥断面 }\end{array}$ & $\begin{array}{l}\text { 第二排水沟、永二 } \\
\text { 干沟、银新干沟、 } \\
\text { 四二干沟 }\end{array}$ & $\mathrm{NH}_{3}-\mathrm{N}$ & 12 月浓度升高 $0.39 \mathrm{mg} / \mathrm{L}$ & $\begin{array}{l}12 \text { 月第二排水沟 } \mathrm{NH}_{3}-\mathrm{N} \text { 浓度 } 82.8 \mathrm{mg} / \mathrm{L} \text { (11月浓度9. } 1 \text { 倍); } \\
12 \text { 月永二干沟 } \mathrm{NH}_{3}-\mathrm{N} \text { 浓度 } 24.5 \mathrm{mg} / \mathrm{L} \text { (11月浓度4. 9倍) }\end{array}$ & $\begin{array}{l}\text { 第二排水沟 } \\
\text { 永二干沟 }\end{array}$ \\
\hline
\end{tabular}

因此，削减入黄污染量是改善黄河水质的唯一途径。 卫宁段应加强第四排水沟和红柳沟的 $\mathrm{NH}_{3}-\mathrm{N}$ 入黄量控制; 青石段应严格清水沟、南干沟和中干沟入黄 $\mathrm{COD}_{\text {㛣、 }} 、 \mathrm{NH}_{3}-\mathrm{N}$ 和TP总量控制, 削减第二排水沟和永二干沟的 $\mathrm{NH}_{3}-\mathrm{N}$ 入黄 总量, 以达到减小黄河水体污染风险的目标。

\subsection{2. 排水沟水质改善情况下水质预警}

根据《宁夏回族自治区环境保护行动计划（2014年 -2017年）》的主要目标, “按照国家和自治区环境保护 目标任务, 要求进一步深化污染防治, 严格环境监管, 改 善环境质量, 在 2017 年把中国黄河宁夏段11条直接入黄排 水沟水质控制在IV类, 5 个国控监测断面水质稳定在III类, 黄河支流泾河、清水河出境断面水质稳定在 II IIII类, 重 要湖泊湿地水质稳定在III类”。因此, 本次以此保护目标 为依据, 即排水沟入黄水质达到 $\mathrm{IV}$ 类水质标准, 进行了不 同水文年条件下排水沟水质改善的黄河水质预警研究 ${ }^{[17]}$ 。

为明确入境水量对黄河水质的影响, 根据2000-2012 年黄河干流入境断面 (下河沿水文站) 流量资料, 利用水 文频率软件Pearson III型分布曲线进行配线, 分别以 $25 \%$ 、 50\%和75\%保证率对应的流量作为丰水年、平水年和枯水年 黄河干流宁夏段入境水量, 在已有的实测系列中选取与设 计值相等或接近的真实年份作为相应的丰、平、枯代表年, 最终选得2011年、2008年和2003年入境流量作为丰、平、 枯代表年，进行不同水文年的黄河水质预警研究。

(1) 卫宁段

由图7至图9可知, 排水沟水质改善情况下, 丰、平、 枯水年金沙湾断面 $\mathrm{COD}_{\mathrm{Mn}} 、 \mathrm{NH}_{3}-\mathrm{N}$ 和TP浓度变化趋势一致, 丰水年水质浓度小, 相对来说水质好, 而枯水年水质浓度

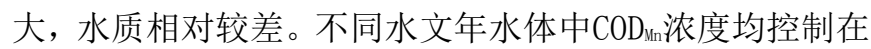
II类标准以内, 为绿色预警状态, 轻警。其中， 3、4、9 月水质 $\mathrm{COD}_{\mathrm{Wn}_{\mathrm{N}}}$ 浓度满足 $\mathrm{I}$ 类水质标准, 为蓝色预警状态, 无 警情。不同水文年黄河水体 $\mathrm{NH}_{3}-\mathrm{N}$ 浓度年内变幅大, 断面 水体在年内主要为 II类水, 绿色预警状态, 轻警。其中, 3、10月水质变差, 达到黄色预警状态, 中警； 6月水质相 对较好为I类水, 蓝色预警状态, 无警情。TP浓度在不同 水文年的3、11、12月水质变化较大, 基本满足 II类水质
标准，绿色预警状态，轻警，仅在6、7、8、11月存在水 体水质恶化为III类水, 黄色预警状态, 中警。

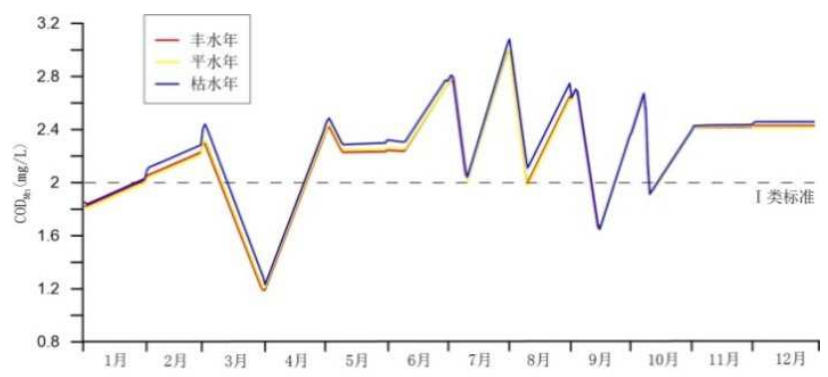

图7 排水沟水质改善情况下金沙湾断面不同水文年水体 $\mathrm{CDD}_{\text {॥nn }}$ 浓度历时 曲线。

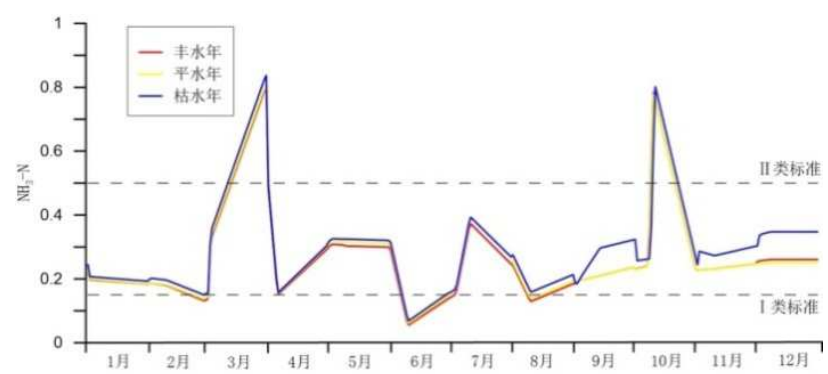

图8 排水沟水质改善情况下金沙湾断面不同水文年水体 $\mathrm{NH}_{3}-\mathrm{N}$ 浓度历时 曲线。

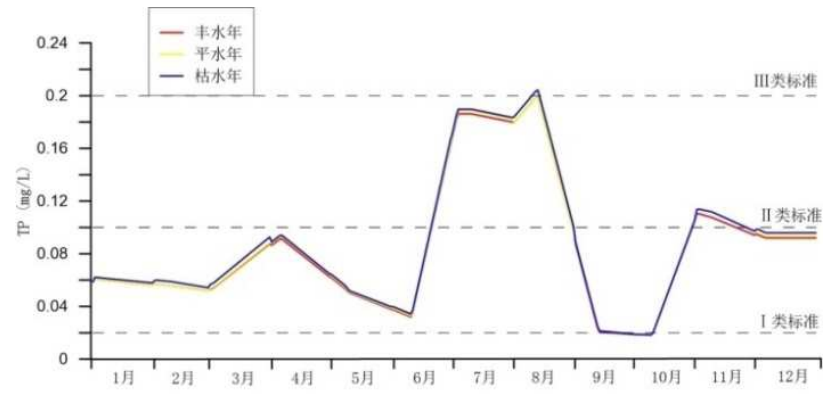

图9 排水沟水质改善情况下金沙湾断面不同水文年水体 $\mathrm{TP}$ 浓度历时曲 线。 
表 3 为金沙湾断面不同水文年预警指标浓度表，由表 可知，在不同水文年，预警指标浓度最大值、最小值基本 相同。可见, 在排水沟水质改善情况下, 由于卫宁段入黄 排水沟数量少, 水体的自净能力使得其对黄河水体的影响 程度有限，金沙湾断面水质基本不受上游来水量影响。

表3 卫宁段金沙湾断面不同水文年预警指标浓度表。

\begin{tabular}{lllllll}
\hline \multirow{2}{*}{$\begin{array}{l}\text { 预警指 } \\
\text { 标 }\end{array}$} & \multicolumn{2}{l}{ 丰水年 $(\mathrm{mg} / \mathrm{L})$} & \multicolumn{2}{c}{ 平水年 $(\mathrm{mg} / \mathrm{L})$} & \multicolumn{2}{c}{ 枯水年 $(\mathrm{mg} / \mathrm{L})$} \\
\cline { 2 - 7 } & 最大值 & 最小值 & \multicolumn{1}{l}{ 最大值 } & 最小值 & 最大值 & 最小值 \\
\hline $\mathrm{COD}_{\text {wn }}$ & 3.00 & 1.19 & 3.01 & 1.20 & 3.08 & 1.23 \\
$\mathrm{NH}_{3}-\mathrm{N}$ & 0.80 & 0.06 & 0.81 & 0.06 & 0.84 & 0.07 \\
$\mathrm{~T}-\mathrm{P}$ & 0.20 & 0.02 & 0.20 & 0.02 & 0.20 & 0.02 \\
\hline
\end{tabular}

（2）青石段

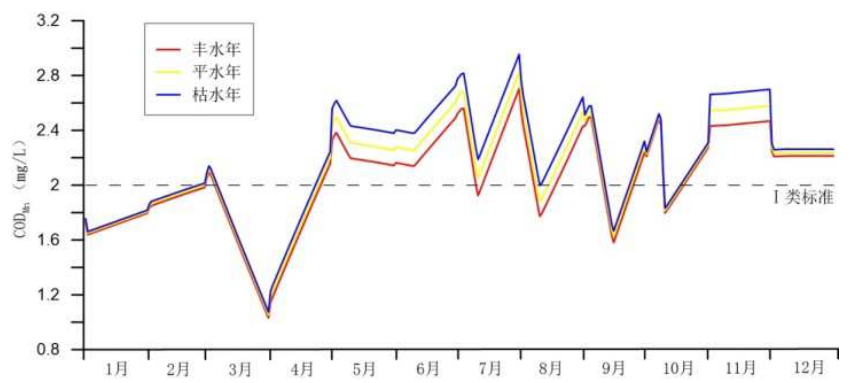

图10 排水沟水质改善情况下叶盛公路桥断面不同水文年水体 $\mathrm{COD}_{\text {un }}$ 浓度 历时曲线。

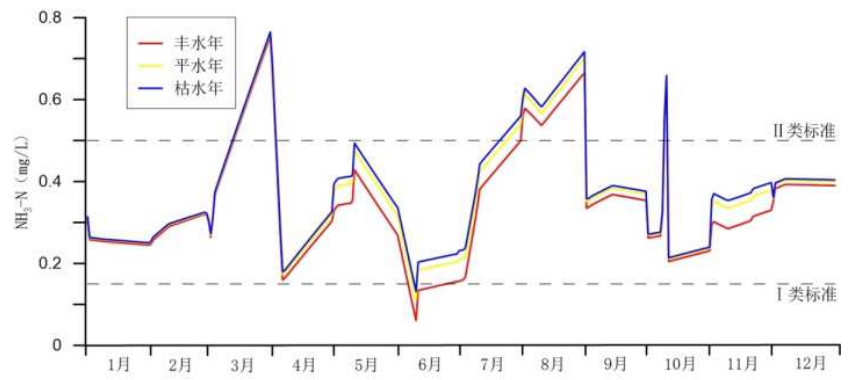

图11 排水沟水质改善情况下叶盛公路桥断面不同水文年水体 $\mathrm{NH}_{3}-\mathrm{N}$ 浓度 历时曲线。

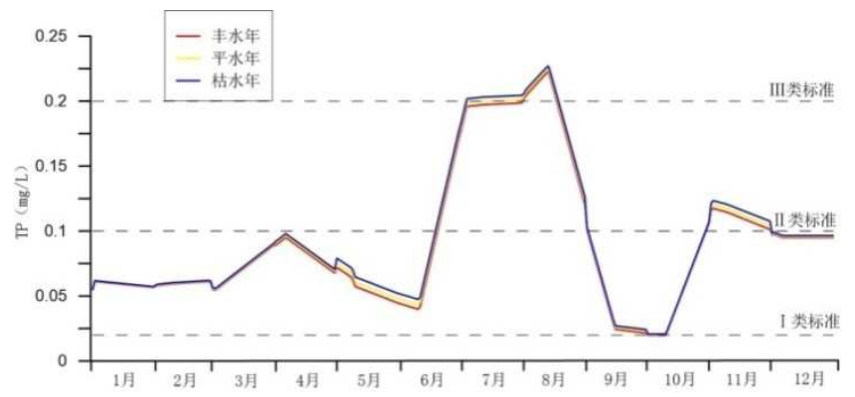

图12 排水沟水质改善情况下叶盛公路桥断面不同水文年水体TP浓度历 时曲线。

青石段叶盛公路桥断面不同水文年 $\mathrm{COD}_{\mathrm{Mn}} 、 \mathrm{NH}_{3}-\mathrm{N}$ 和TP 浓度曲线见图10至图12。由图可知, 丰水年污染物浓度最 小，枯水年污染物浓度最大，并且相对于水体TP浓度，不 同上游来水量对此断面水体 $\mathrm{COD}_{\mathrm{Nn}} 、 \mathrm{NH}_{3}-\mathrm{N}$ 浓度影响较大。
断面水体 $\mathrm{COD}_{\mathrm{Mn}}$ 浓度在年内呈增加的趋势，1-4月基本满足 I 类水质标准, 无警情; 5-12月水质满足II类水质标准, 达 到绿色预警状态, 轻警。 $\mathrm{NH}_{3}-\mathrm{N}$ 浓度年内波动范围较大, 总体上满足II类水质标准, 为绿色预警, 警情较轻, 3、8、 10月部分时间达到黄色预警状态。TP浓度在6、9、11月为 III类水, 呈黄色预警状态; 其他月基本为II类水, 为蓝 色预警状态，无警情。

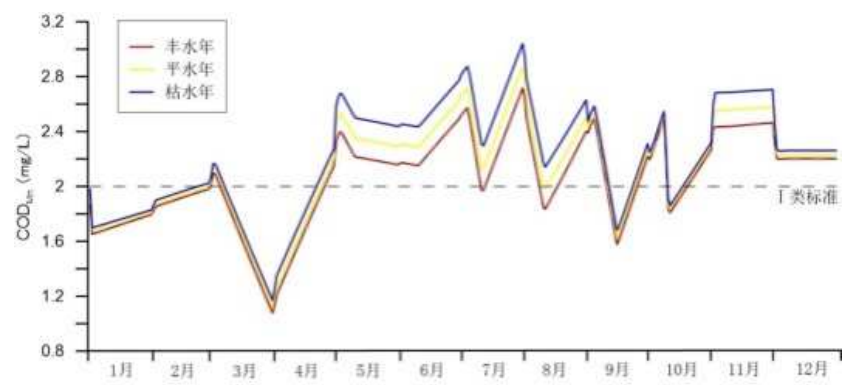

图13 排水沟水质改善情况下银古公路桥断面不同水文年水体COD浓度 历时曲线。

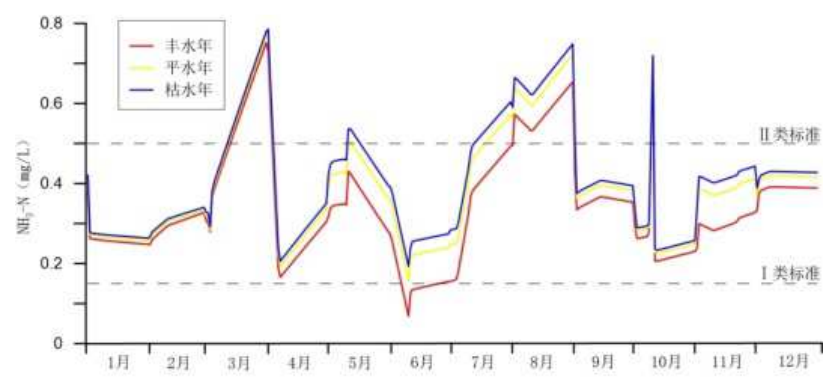

图14 排水沟水质改善情况下银古公路桥断面不同水文年水体 $\mathrm{NH}_{3}-\mathrm{N}$ 浓度 历时曲线。

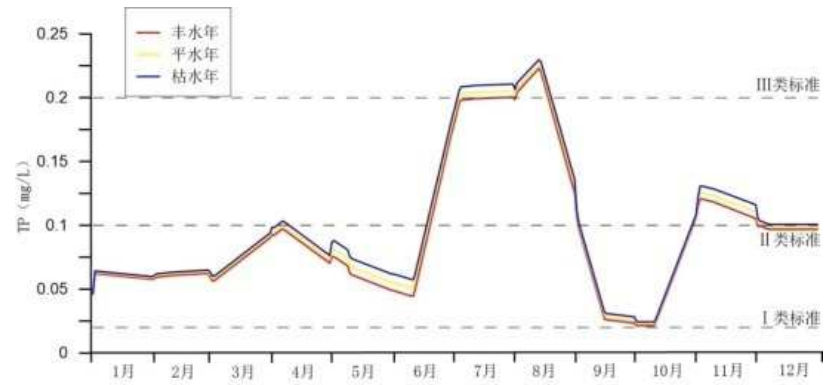

图15 排水沟水质改善情况下银古公路桥断面不同水文年水体TP浓度历 时曲线。

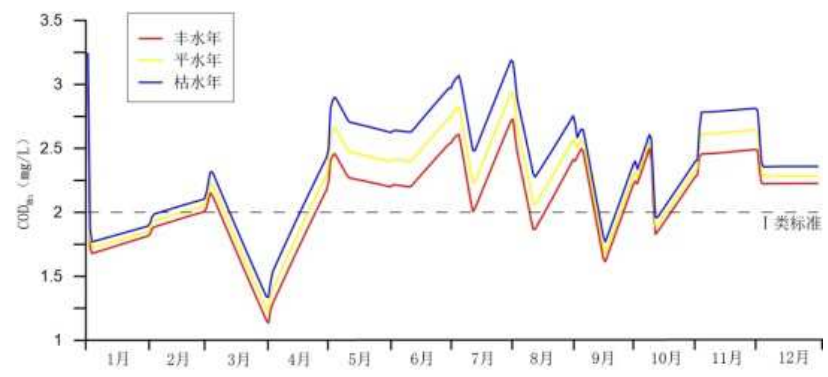

图16 排水沟水质改善情况下平罗黄河大桥断面不同水文年水体 $\mathrm{CD}_{\text {将浓 }}$ 度历时曲线。 


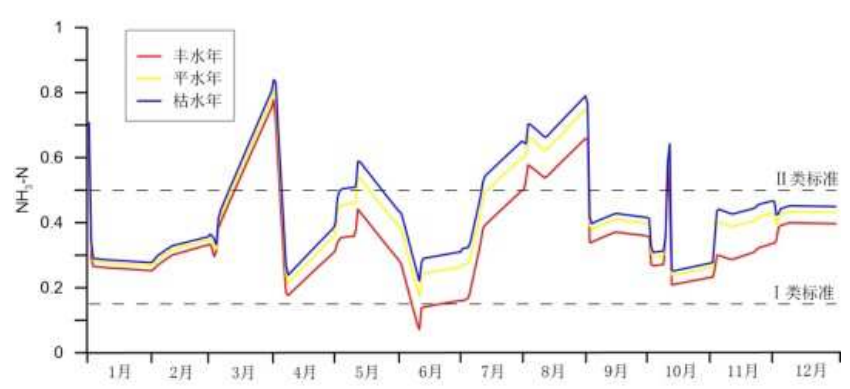

图17 排水沟水质改善情况下平罗黄河大桥断面不同水文年水体 $\mathrm{NH}_{3}-\mathrm{N}$ 浓 度历时曲线。

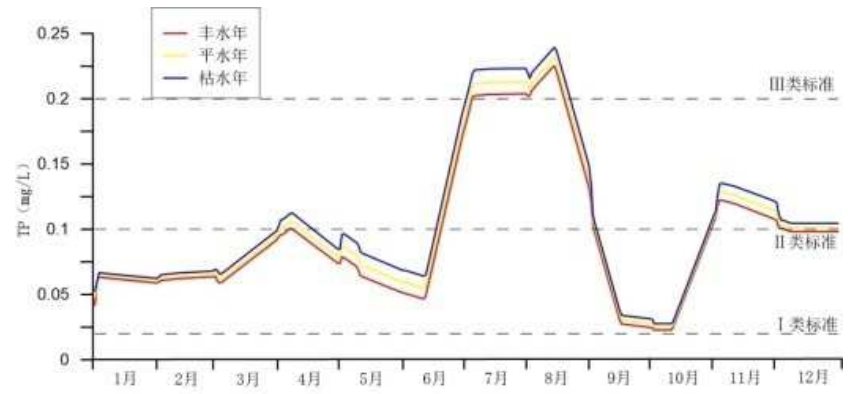

图18 排水沟水质改善情况下平罗黄河大桥断面不同水文年水体TP浓度 历时曲线。

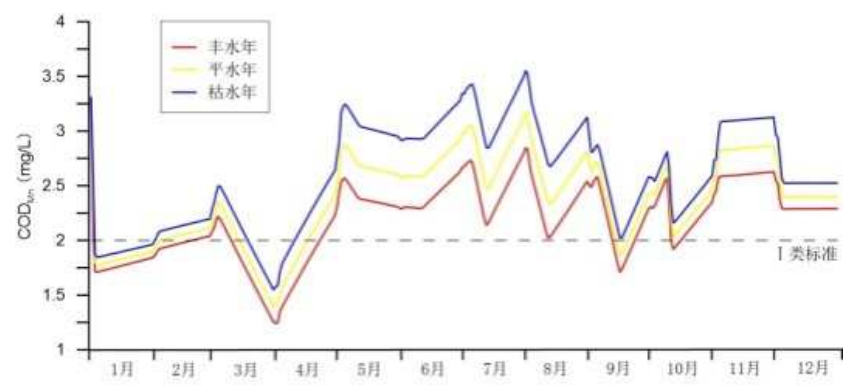

图19 排水沟水质改善情况下麻黄沟断面不同水文年水体 $\mathrm{COD}_{\mathrm{IIn}}$ 浓度历时 曲线。

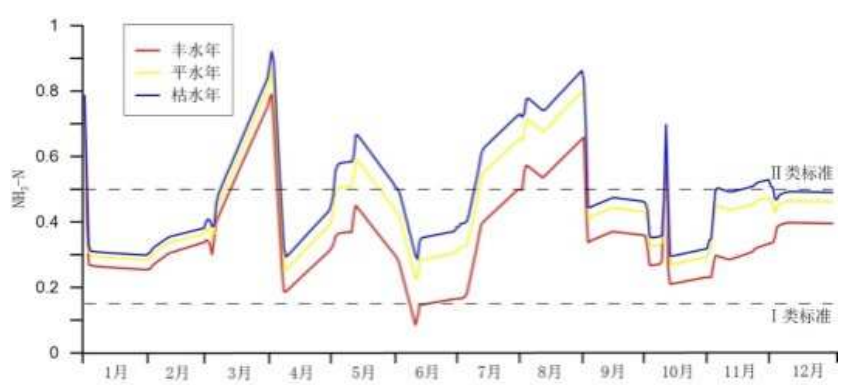

图20 排水沟水质改善情况下麻黄沟断面不同水文年水体 $\mathrm{NH}_{3}-\mathrm{N} / 冖^{2}$ 度历时 曲线。

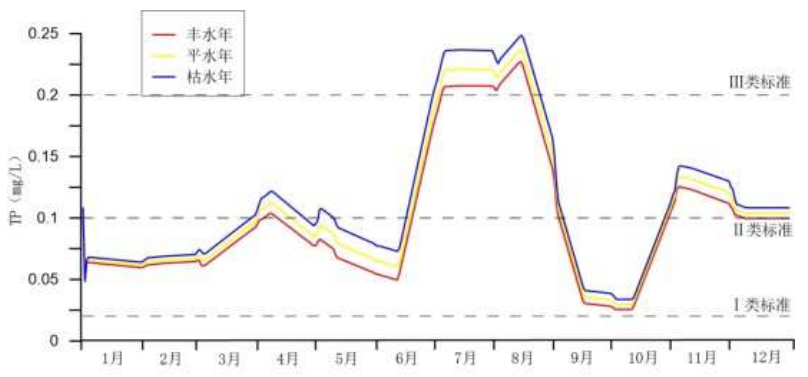

图21 排水沟水质改善情况下麻黄沟断面不同水文年水体TP浓度历时曲 线。

丰平枯水年银古公路桥断面、平罗黄河大桥断面和麻 黄沟断面水体 $\mathrm{COD}_{\mathrm{In}} 、 \mathrm{NH}_{3}-\mathrm{N}$ 和TP浓度历时曲线见图13至图 21。由图可知, 银古公路桥断面、平罗黄河大桥断面和麻 黄沟断面水体 $\mathrm{COD}_{\text {Inn }} 、 \mathrm{NH}_{3}-\mathrm{N}$ 浓度均满足或优于II类水质标 准, 为绿色或蓝色预警状态, 警情较轻; 三个断面水体 $\mathrm{TP}$ 浓度均满足III类或II类水质标准, 为黄色或绿色预警状 态，警情为中警或轻警。

综上可知, 不同上游来水条件下, 枯水年浓度相对较 大，平水年次之，丰水年最小。表 4 为卫宁段叶盛公路桥 断面、银古公路桥断面、平罗黄河大桥断面和麻黄沟断面 不同水文年预警指标浓度年内最大值、最小值。由图可知, 在排水沟水质改善情况下, 尽管不同来水条件下沿程断面 水体污染物浓度有所变化, 但浓度差值相对较小, 即中国 黄河水体中浓度受上游来水量影响较小。

表4 青石段监测断面不同水文年预警指标浓度表。

\begin{tabular}{|c|c|c|c|c|c|c|c|}
\hline \multirow{2}{*}{ 断面 } & \multirow{2}{*}{ 预警指标 } & \multicolumn{2}{|c|}{ 丰水年 (mg/L) } & \multicolumn{2}{|c|}{ 平水年 (mg/L) } & \multicolumn{2}{|c|}{ 枯水年 (mg/L) } \\
\hline & & 最大值 & 最小值 & 最大值 & 最小值 & 最大值 & 最小值 \\
\hline \multirow{3}{*}{ 叶盛公路桥断面 } & $\mathrm{COD}_{\mathrm{yn}}$ & 2.70 & 1.03 & 2.82 & 1.05 & 2.95 & 1.07 \\
\hline & $\mathrm{NH}_{3}-\mathrm{N}$ & 0.75 & 0.06 & 0.76 & 0.11 & 0.76 & 0.13 \\
\hline & $\mathrm{TP}$ & 0.22 & 0.02 & 0.22 & 0.02 & 0.23 & 0.02 \\
\hline \multirow{3}{*}{ 银古公路桥断面 } & $\mathrm{COD}_{\mathrm{Wn}}$ & 2.72 & 1.08 & 2.87 & 1.12 & 3.04 & 1.17 \\
\hline & $\mathrm{NH}_{3}-\mathrm{N}$ & 0.75 & 0.07 & 0.77 & 0.16 & 0.79 & 0.19 \\
\hline & $\mathrm{TP}$ & 0.22 & 0.02 & 0.23 & 0.02 & 0.23 & 0.02 \\
\hline \multirow{3}{*}{ 平罗黄河大桥断面 } & $\mathrm{COD}_{\mathrm{un}}$ & 2.98 & 1.14 & 3.17 & 1.23 & 3.24 & 1.34 \\
\hline & $\mathrm{NH}_{3}-\mathrm{N}$ & 0.78 & 0.07 & 0.81 & 0.17 & 0.84 & 0.22 \\
\hline & $\mathrm{TP}$ & 0.23 & 0.02 & 0.23 & 0.03 & 0.24 & 0.03 \\
\hline \multirow{3}{*}{ 麻黄沟断面 } & $\mathrm{COD}_{\mathrm{un}}$ & 3. 29 & 1.24 & 3.29 & 1. 39 & 3.55 & 1.55 \\
\hline & $\mathrm{NH}_{3}-\mathrm{N}$ & 0.79 & 0.09 & 0.87 & 0.23 & 0.92 & 0.29 \\
\hline & TP & 0.23 & 0.03 & 0.24 & 0.03 & 0.25 & 0.03 \\
\hline
\end{tabular}




\section{4. 结论}

本文主要分析模拟了中国黄河宁夏段水质, 考虑直接 入黄排水沟, 及主要污染工厂的排放对黄河水体水质的影 响。其中卫宁段沿程相对较短且排水沟少, 水质相对较好, 而青石段沿程较长, 排水沟直排点众多且沿河两岸工厂较 多，对中国黄河水质影响明显。根据对现状年及不同来水 状况下水质改善后的预警结果分析, 得出结论: 中国黄河 宁夏段水质主要受到沿岸排水沟排放浓度的影响, 而不同 水文年来水状况对其影响较小, 因此对于中国黄河水质的 改善, 需要控制主要入黄排水沟排放浓度。其中卫宁段需 要控制第四排水沟、红柳沟, 青石段需要控制第二排水沟、 永二干沟、灵武东沟排污浓度使其排放浓度达到III类水 标准, 以及严格控制黄河两岸工厂的污水废渣排放。

\section{基金项目}

银川平原地下水对变化条件的响应机制及合理开发利用 研究 (41172212)

\section{参考文献}

[1] 任学蓉, 周怀东, 李卫东. 黄河宁夏段氨氮污染状态分析 $[J]$. 中国水利: 水污染防治, 2006. 5:40-42。

２］张爱平, 杨世琦, 易军, 等. 宁夏引黄灌区水体污染现状及污 染源解析 [J]. 中国生态农业学报, 2010, 18 (6) : 1295-1297。

[3] 岳志春, 马晓阳, 张红武. 黄河下河沿至青铜峡段河道整治 模型试验研究 [J]. 人民黄河, 2015, 37 (6) : 36-37。

[4] 云飞, 李燕, 杨建宁, 等. 黄河宁夏段 COD及氨氮污染动态分 布模拟探讨 $[\mathrm{J}]$. 宁夏大学学报: 自然科学 版, 2005, 26 (3) : 283-284。

[5] 马晓阳, 岳志春. 黄河宁夏段河道治理存在的问题与对策 [J]. 宁夏工程技术, 2014, 13 (4) : 366-367。
６］范小黎, 王随继, 由立山. 黄河宁夏河段河道演变及其影响 因素分析 $[J]$. 水资源与水工程学报, 2010,21(1):5-11。

[7] Ta Wanquan , Hong lang Xiao, Zhibao Dong. Long-term Morphodynamic Changes of a Desert Reach of the Yellow River Following Upstream Large Reservoirs' Operation [J]. Geomorphology, 2008, 97:249 -259.

[8] 程一曼. 基于WASP7的渭河陕西段水质模拟分析研究 [D]. 西 安: 西北大学, 2008。

[9] 张永祥, 王否, 姚伟涛, 张丽云. WASP模型参数率定与敏感 性分析 [J]. 水资源与水工程学报, 2009, 20 (5) :28-30。

[10] 龚然, 徐进, 邵燕平. WASP模型湖库水环境模拟国内外研究 进展综述 [J]. 环境科学与管理, 2014, 39(10) : 15-18。

[11] 于顺东. WASP水质模型应用与D0模型评价 [D]. 天津: 天津 大学, 2007 。

[12] 彭森. 基于WASP模型的不确定性水质模型研究 [D]. 天津: 天 津大学, 2010。

[13] Ernst MR, Owens J. Development and application of a WASP model on a large Texas reservoir to assess eutrophication control [J]. Lake and Reservoir Management, 2009, 25 (2) : 136-148.

[14] Bhuyan S J, Koellker J K, et a1. An integrated approach for water quality assessment of Kansas basin [J]. Environmental Modeling and Sorware, 2003, 1 8:473483.

[15] 陈洁. 宁夏沙湖水环境预警研究 [D]. 西安: 长安大学, 2014。

[16] 胡琋. 基于 WASP 模型的湘江湘潭段水质目标管理研究 [D]. 湖南: 湘潭大学, 2013。

[17］宁夏回族自治区人民政府办公厅．宁夏回族自治区环境保 护行动计划作 http://www. nx. gov. cn/zwgk/gtwj/nzbf/87935. htm. 2013 .12. 27. 